\title{
Antimicrobial Activity of Goat Colostrum against Bacterial Strains Causing Food Poisoning Diseases
}

\author{
Triana Setyawardani $^{1^{*}}$, Juni Sumarmono ${ }^{1}$, Heni Risqiati ${ }^{2}$ and Setya Agus Santosa \\ ${ }^{1}$ Faculty of Animal Science, Jenderal Soedirman University, Purwokerto 53123, Central Java,, Indonesia \\ ${ }^{2}$ Department of Agriculture, Faculty of Animal Science and Agriculture, Diponegoro University, Semarang, Indonesia \\ *Corresponding author email: trianaunsoed@gmail.com
}

\begin{abstract}
The study was aimed to investigate the antimicrobial activity of bacterial isolates L.plantarum 3CT7 and 20CT8 from goat colostrum. The antimicrobial activity of cell-free supernatant was tested using a welldiffusion method on several indicators: temperature, time of storage, and $\mathrm{pH}$. Antimicrobial activity was recorded in both isolates at $\mathrm{pH} 2.0 ; 4.0 ; 6.0$ and 8.0 , temperature at 0,50 and $100^{\circ} \mathrm{C}$, and in cold storage for 0 , $15,30,45$ and 60 days. L.plantarum 7CT3 and L.plantarum 20CT8 have a bigger zone of inhibition than that of Pseudomonas spp. as compared to other bacteria. Testing the cell-free activity was aimed to investigate the metabolite inhibition by L.plantarum. The isolates were capable of inhibiting all pathogenic bacteria in the experiment (S. thypimurium, E. coli, and S. aureus) as evidenced from the similar zone of inhibition from 15.83 to $16.06 \mathrm{~mm}$. Isolates (L.plantarum 7CT3 dan 20CT8) exhibit inhibitory properties against S.thypimurium, S.aureus, Pseudomonas spp.. and L.monocytogenes at 0,50 and $100^{\circ} \mathrm{C}$. L.plantarum $7 \mathrm{CT} 3$ and L.plantarum $20 \mathrm{CT} 8$ exhibit antimicrobial activity during cold storage. Both isolates grown in the range of $\mathrm{pH}$ from 2 to 8 could inhibit S.thypimurium, E.coli, S. aureus and Pseudomonas spp. In general, the two isolates are the potential antimicrobial activity with broad ranges of $\mathrm{pH}$, temperature and storage time.
\end{abstract}

Keywords: isolate, antimicrobial activity, temperature, $\mathrm{pH}$, storage time

Abstrak. Penelitian ini bertujuan untuk mengetahui aktivitas antimikroba isolat bakteri L.plantarum 3CT7 dan 20 CT8 dari kolostrum kambing. Aktivitas antimikroba dari supernatan bebas sel diuji menggunakan metode difusi pada beberapa indikator yaitu : suhu, waktu penyimpanan, dan $\mathrm{pH}$. Aktivitas antimikroba diamati pada kedua isolat tersebut pada $\mathrm{pH} 2,0 ; 4,0 ; 6,0$ dan 8,0 , suhu 0,50 dan $100^{\circ} \mathrm{C}$, dan pada penyimpanan dingin selama $0,15,30,45$ dan 60 hari. Isolat L.plantarum 7CT3 dan L.plantarum 20CT8 memiliki zona penghambatan lebih besar pada bakteri Pseudomonas spp. dibandingkan dengan bakteri uji lainnya. Pengujian aktivitas bebas sel bertujuan untuk mengamati kemampuan daya hambat metabolit yang dihasilkan L.plantarum. Isolat yang diujikan mampu menghambat semua bakteri patogen (S.thypimurium, E.coli, dan S.aureus) dan zona penghambatan yang diperoleh yaitu 15,83 sampai dengan 16,06 mm. Isolat (L.plantarum 7CT3 dan 20CT8) menunjukkan sifat penghambatan terhadap S.thypimurium, S.aureus, Pseudomonas spp. dan L.monocytogenes pada suhu 0,50 and $100^{\circ} \mathrm{C}$. Kedua isolat yaitu L.plantarum 7CT3 dan L.plantarum $20 \mathrm{CT} 8$ menunjukkan aktivitas antimikroba selama penyimpanan dingin. Kedua isolat yang tumbuh dalam kisaran pH dari 2 hingga 8 dapat menghambat S.thypimurium, E.coli, S.aureus dan Pseudomonas spp. Secara umum, kedua isolat tersebut berpeluang sebagai antimikroba potensial dengan rentang $\mathrm{pH}$, suhu, dan waktu penyimpanan yang luas.

Kata kunci: isolat, aktivitas antimikroba, temperatur, pH, lama penyimpanan

\section{Introduction}

The major cause of poisoning in Indonesia during 2017 is instant foods. According to Indonesia Health Authority, the biggest poisoning case happened to women aged 15-34 years old, i.e. 163 cases. (Arisanti et al., 2018) reported that the major cause of food poisoning in Indonesia is pathogenic bacteria (Escherichia coli) from the consumed food product.

One of the measures to prevent food poisoning due to pathogenic bacteria is by using natural preservatives for food processing. Lactic acid bacteria (LAB) are well-recognized for their potential as natural food preservatives. Antimicrobial activity as the natural preservatives is harnessed during food processing and in the digestive tract. $L A B$ produce metabolite with antimicrobial properties that prevent the growth and distribution of pathogenic bacteria and food spoilage. LAB produce lactic acid (Setyawardani et al., 2017) and other organic acids, hydrogen 
peroxide and bacteriocin-like substances (Çadirci and Çitak, 2005).

LAB can be obtained from cow and goat colostrum. Previous study reported that cow colostrum exhibits antimicrobial activity against E.coli, E.aerogenes, K.pneumonieae, B.subtilis and S.aureus. Early presumption of natural preservatives is tested by measuring the inhibition of antimicrobial activity of LAB metabolites. The test was conducted using an agar well diffusion assay method (Khay et al., 2013) to measure the inhibitory properties against the growth, $\mathrm{pH}$ and temperature of the medium (Zouhir et al., 2011)

Metabolite obtained from goat colostrum LAB exhibits antimicrobial properties. Previous study indicated that the antimicrobial activities of $L A B$ from goat milk were successful in inhibiting several gram-positive and gramnegative pathogenic bacteria (Setyawardani et al., 2017). Metabolite produced by goat colostrum $L A B$ is predicted to have the excellent antimicrobial activity to be used as natural food preservatives for food material and food processing. Temperature, storage time, and $\mathrm{pH}$ are the key factors in food processing (Assefa et al., 2008).

The novelty of this study is the production of LAB metabolite from native Indonesian goat colostrum that exhibits an excellent antimicrobial activity as the candidate for natural food preservatives. The study aimed to investigate the inhibition of the antimicrobial activity of native Indonesian goat colostrum LAB based on different factors including temperature, storage time, and $\mathrm{pH}$ of the L.plantarum $3 \mathrm{CT7}$ and L.plantarum 20CT8 isolates.

\section{Materials and Methods}

Testing the Antimicrobial Inhibitory Properties

L.plantarum 7CT3 and L.plantarum 20CT8 were isolated from native Indonesian goat colostrum (unpublished data). Both isolates were grown in MRSB (deMann Rogose Sharp
Broth, Oxoid, USA) and incubated at $37^{\circ} \mathrm{C}$ for $24 \mathrm{~h}$. Cell growth was indicated by the turbidity in the test tube. LAB count was $10^{8} \mathrm{CFU} / \mathrm{ml}$, prepared for inhibitory test against pathogenic and spoilage bacteria. Indicator pathogenic bacteria and spoilage bacteria were cultured in NB media (Nutrient Broth Oxoid, USA) and incubated at $37^{\circ} \mathrm{C}$ for $24 \mathrm{~h}$ until the media turned turbid. Cell count was $10^{8} \mathrm{CFU} / \mathrm{ml}$. An amount of $20 \mu \mathrm{l}$ bacteria was put in petri dish and added with $20 \mathrm{ml}$ of Mueller Hinton Agar $20 \mathrm{ml}$. The agar was let to solid, then wells of 5 $\mathrm{mm}$ diameter were punched into the agar, filled with $20 \mu \mathrm{l}$ isolates for antimicrobial activity test and allowed to diffuse at low temperature (5$8^{\circ} \mathrm{C}$ ) for 60 minutes. The petri dish was incubated at $37^{\circ} \mathrm{C}$ for $24 \mathrm{~h}$. The clear zone forming in the well was measured using calipers. Measurement was conducted three times at different locations, and the mean value of the result was obtained.

\section{Antimicrobial Cell-Free Supernatant}

L.plantarum 7CT3 and L.plantarum 20CT8 isolates were cultured in 10 MRSB media and incubated at $37^{\circ} \mathrm{C}$ for $20 \mathrm{~h}$ until the media turned opaque which indicated the growth of bacteria. L.plantarum 7CT3 and 20CT8 isolates were collected and centrifuged at $7000 \mathrm{rpm}$ speed for 20 minutes at $4^{\circ} \mathrm{C}$. Cell-free supernatant was filtered using a $0.22 \mu \mathrm{m}$ diameter membrane and neutralized. $\mathrm{NaOH} 1 \mathrm{~N}$ was added to the supernatant to yield $\mathrm{pH} \mathrm{5,8-}$ 6,2 . Antimicrobial test was conducted using a well diffusion method.

\section{Antimicrobial Testing at Different Temperature}

The cell-free supernatant that was obtained from the previous step was tested for temperature durability. Antimicrobial durability was tested at 0,50 and $100^{\circ} \mathrm{C}$ for 20 minutes. Inhibition was tested using a well diffusion method.

\section{Antimicrobial Durability Test at Different pH}

The cell-free supernatant of the two isolates was tested for durability at $\mathrm{pH} 2,4,6$ and 8 . The 
$\mathrm{pH}$ of cell-free supernatant was adjusted according to treatment by adding $1 \mathrm{~N} \mathrm{HCl}$ and $1 \mathrm{~N} \mathrm{NaOH}$. The test was conducted using a well diffusion method.

\section{Antimicrobial Test in Cold Storage}

A cold storage is pivotal in investigating microbial durability and activity at specific temperature and duration. Cell-free supernatant was stored for $0,15,30,45$ and 60 days at $4^{\circ} \mathrm{C}$. The test was conducted using a well diffusion method.

\section{Data Analysis}

The obtained data was calculated to obtain the mean value and standard deviation. A further test was conducted using a Duncan's Multiple Range Test (DMRT).

\section{Result and Discussion}

\section{Antimicrobial Activity of Crude Extract}

Table 1 shows that L.plantarum 7CT3 and L.plantarum 20CT8 have a bigger zone of inhibition in Pseudomonas spp. compared to other bacteria, indicating a significant difference $(p<0.05)$. The smallest zone of inhibition in L.plantarum 7CT3 and L.plantarum $20 \mathrm{CT} 8$ isolates was S.aureus, measuring 13.00 and $13.67 \mathrm{~mm}$, respectively. In general, both isolates showed inhibitory activity against pathogenic and spoilage bacteria. Antimicrobial activity of the isolates from L.plantarum 7CT3 and 20CT8 was produced from metabolite in form of acid. The acid lowered $\mathrm{pH}$ and lysed the indicator bacteria, namely S.thypimurium, E.coli, S.aureus, and Pseudomonas spp. One of the inhibitory mechanisms was $\mathrm{pH}$ reduction by
LAB metabolites, i.e. lactic acid and acetic acid (Tejero-Sariñena et al., 2012). The neutralizing process in the supernatant culture using alkali did not reduce the antimicrobial activity. It is evidenced that the metabolites yield were the potential candidates for bacteriocin. L.plantarum isolates are the group of Lactobacili with a high production of acid that can lower $\mathrm{pH}$ faster than other isolates, such as L.fermentum (Tejero-Sariñena et al., 2012). The cell-free supernatant contains active metabolites which function as the initial indicator of bacteriocin (Hartmann et al., 2011).

Antimicrobial activity is generated by lactic acid and other organic acids (Teneva et al., 2017) (Teneva et al., 2017). L.plantarum TW 4 exhibits antimicrobial properties against some pathogenic and spoilage bacteria (Setyawardani et al., 2014). The inhibitory properties of L.plantarum against pathogenic and spoilage bacteria are organic acids which reduce $\mathrm{pH}$ value and created an inhibition zone. The organic acids produced by L.plantarum are mainly lactic acid. Some strains of L.plantarum are the potential natural preservatives for food industry, and therapy for microbial infection (Dinev et al., 2018).

\section{Antimicrobial Activity of Cell-Free}

Figure 1 shows that the mean inhibition zone created by L.plantarum 7CT3 and L.plantarum 20 CT8 is 12.94 to $18.67 \mathrm{~mm}$. L.plantarum 7CT3 isolates shows a higher inhibition that that of L.plantarum 20 CT8 against pathogenic bacteria but not against spoilage bacteria (Pseudomonas spp.). The cell free activity was tested to observe the

Table 1. Inhibition zone diameter of L.plantarum crude extracts in different bacteria indicators

\begin{tabular}{lcc}
\hline \multirow{2}{*}{ Indicator bacteria } & \multicolumn{2}{c}{ Inhibition zone diameter $(\mathrm{mm})$} \\
\cline { 2 - 3 } & L.plantarum 7 CT3 & L.plantarum 20CT8 \\
\hline S. thypimurium & $15.33 \pm 0.58^{\mathrm{b}}$ & $15.33 \pm 0.58^{\mathrm{b}}$ \\
E. coli & $15.00 \pm 0.00^{\mathrm{b}}$ & $14.67 \pm 0.58^{\mathrm{bc}}$ \\
S.aureus & $13.00 \pm 0.00^{\mathrm{c}}$ & $13.67 \pm 0.58^{\mathrm{c}}$ \\
Pseudomonas spp. & $18.00 \pm 0.00^{\mathrm{a}}$ & $18.00 \pm 0.00^{\mathrm{a}}$ \\
L.monocytogenes $^{\mathrm{a}}$ & $14.33 \pm 0.58^{\mathrm{b}}$ & $15.00 \pm 1.00^{\mathrm{b}}$ \\
\hline
\end{tabular}

Values bearing different superscripts within column show significant difference $(P<0.05)$ 


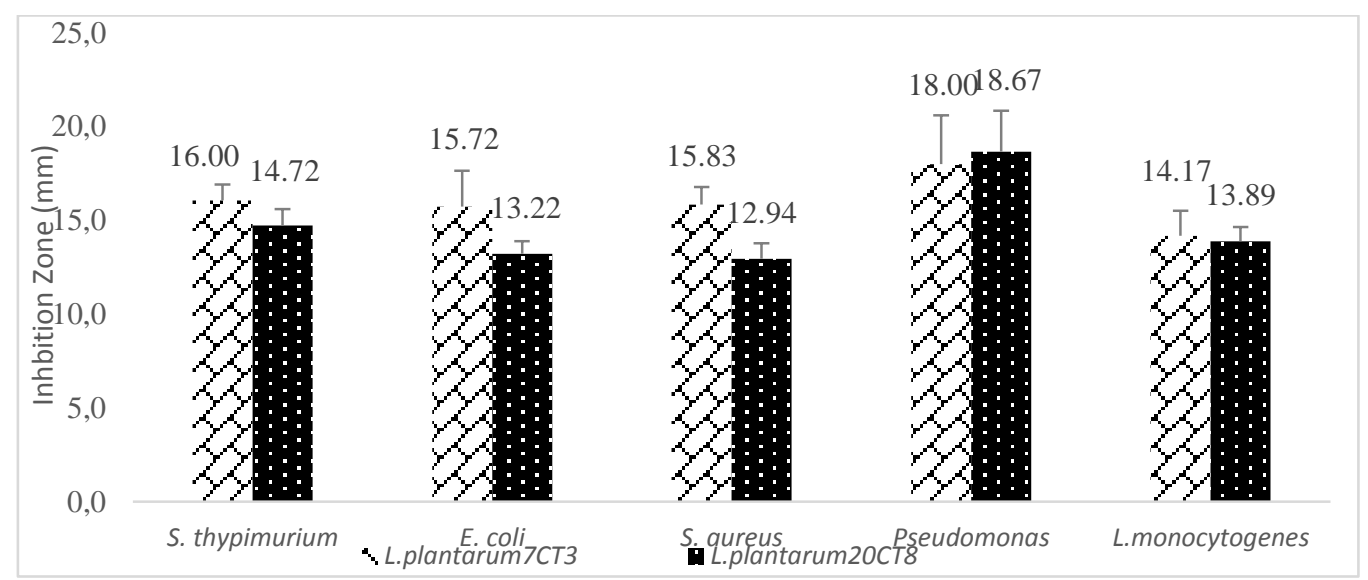

Figure 1. Average zone of inhibition $(\mathrm{mm})$ of L.plantarum cell-free

Table 2. Zone of inhibition of L.plantarum isolates at different temperatures

\begin{tabular}{lcccccc}
\hline \multicolumn{1}{c}{ Indicator bacteria } & \multicolumn{3}{c}{ L.plantarum 7CT3 } & \multicolumn{3}{c}{ L.plantarum 20CT8 } \\
\hline & \multicolumn{1}{c}{$0^{\circ} \mathrm{C}$} & \multicolumn{1}{c}{$50^{\circ} \mathrm{C}$} & $100^{\circ} \mathrm{C}$ & $0^{\circ} \mathrm{C}$ & $50^{\circ} \mathrm{C}$ & $100^{\circ} \mathrm{C}$ \\
\hline S. thypimurium & $13.3 \pm 0,5^{\mathrm{b}}$ & $12.3 \pm 0,5^{\mathrm{c}}$ & $15.0 \pm 0,0^{\mathrm{a}}$ & $1.3 \pm 1.5^{\mathrm{c}}$ & $16.0 \pm 0.5^{\mathrm{b}}$ & $17.7 \pm 1.1$ \\
E. coli & $13 \pm 0.0^{\mathrm{b}}$ & $0 \pm 0.0^{\mathrm{d}}$ & $11.67 \pm 1.5^{\mathrm{b}}$ & $16 \pm 0.0^{\mathrm{ab}}$ & $16 \pm 0.0^{\mathrm{b}}$ & $17 \pm 0.0$ \\
S. aureus & $13.0 \pm 1.0^{\mathrm{b}}$ & $12.3 \pm 0,5^{\mathrm{c}}$ & $14.7 \pm 0,5^{\mathrm{a}}$ & $17.0 \pm 0,0^{\mathrm{ab}}$ & $15.3 \pm 0.5 \mathrm{~b}$ & $17.3 \pm 0.5$ \\
Pseudomonas spp. & $20.0 \pm 0,0^{\mathrm{a}}$ & $15.7 \pm 0.0^{\mathrm{a}}$ & $15.3 \pm 0.5^{\mathrm{a}}$ & $15.0 \pm 0.0^{\mathrm{bc}}$ & $18.0 \pm 0.0^{\mathrm{a}}$ & $18.0 \pm 0.0$ \\
L. monocytogenes & $11.3 \pm 0.5^{\mathrm{c}}$ & $13.3 \pm 0.5^{\mathrm{b}}$ & $13.0 \pm 0.0^{\mathrm{b}}$ & $15.0 \pm 0.0^{\mathrm{bc}}$ & $15.3 \pm 0.5^{\mathrm{b}}$ & $17.0 \pm 0.0$ \\
\hline
\end{tabular}

Values bearing different superscripts within column show significant difference $(P<0.05)$

metabolite inhibition by L.plantarum. The two isolates showed different inhibitory properties $(\mathrm{P}<0.05)$.L.plantarum 7CT3 and L.plantarum 20 CT8 show a higher inhibition against Pseudomonas spp., indicating a significant difference from the inhibition against pathogenic bacteria $(P<0.05)$. L.plantarum 7 CT3 isolates had the lowest zone of inhibition in L.monocytogenes, namely $14.17 \mathrm{~mm}$. The isolates were capable of inhibiting all pathogenic bacteria in the experiment (S.thypimurium, E.coli, and S.aureus) as evidenced from the similar zone of inhibition ( $P>0.05$ ) from 15.83 to $16.06 \mathrm{~mm}$. L.plantarum 20 CT8 showed the smallest zone of inhibition against S.aureus namely $12.94 \mathrm{~mm}$ which is not significantly different $(P>0.05)$ from that of E.coli. The isolates showed a relatively similar zone of inhibition against L.monocytogenes and E.coli except for S.thypimurium.

The same isolates with different strains created different zones of inhibition. Previous study reported that the result of gene sequencing with $16 \mathrm{~S}$ rRNA showed that isolates 7CT3 was included in L.plantarum KCCM200656 and isolates 20 CT8 was under L.plantarum IMAU 40170.

Testing the cell-free activity was aimed to investigate the inhibitory properties of metabolites without the cell produced by L.plantarum. The same isolate with different strains created different zones of inhibition. The previous study reported that $16 \mathrm{~S}$ rRNA gene sequencing indicated that isolates 7CT3 were of L.plantarum KCCM200656 and isolates 20CT8 were of L.plantarum IMAU 40170 (Setyawardani, unpublished data).

\section{Antimicrobial Activity at Different Degrees of Temperature}

Table 2 shows that the two isolates ( $L$. plantarum 7CT3 dan 20CT8) exhibit inhibitory properties against S.thypimurium, S. aureus, Pseudomonas spp. and L. monocytogenes at 0 , 50 and $100^{\circ} \mathrm{C}$. The highest mean value of zone of inhibition in both isolates was observed in Pseudomonas spp.. L. plantarum $20 \mathrm{CT} 8$ isolates 
was capable of inhibiting all bacteria in all degrees of temperature and exhibited a larger zone of inhibition than that of L.plantarum 7CT3. In the $0^{\circ} \mathrm{C}$ cold storage, both isolates could inhibit all the indicator bacteria. L.plantarum 7CT3 isolates showed the higher inhibitory properties against Pseudomonas spp. namely $20 \mathrm{~mm}$, significantly different $(P<0.05)$ from the other indicator bacteria. The lowest inhibition was $11.3 \mathrm{~mm}$ against L.monocytogenes. L.plantarum 7CT3 isolates showed a relatively similar inhibition against S.thypimurium, E.coli and S.aureus. L.plantarum 20 CT8 isolates had a relatively similar inhibition against E.coli, S.aureus, Pseudomonas spp. and L.monocytogenes, while the lowest was against $S$. thypimurium with a significant difference $(\mathrm{P}<0.05)$.

L.plantarum $7 \mathrm{CT} 3$ heated at $50^{\circ} \mathrm{C}$ could inhibit other indicator bacteria except for E.coli. The isolates exhibited the highest inhibition $(15.7 \mathrm{~mm})$ against Pseudomonas spp., significantly different $(P<0.05)$ from other bacteria. At $50^{\circ} \mathrm{C}$, L.plantarum $20 \mathrm{CT} 8$ isolates showed the higher mean of inhibition than that of L.plantarum 7CT3. Inhibitory properties of L.plantarum 20CT8 against S.thypimurium, E.coli, and S.aureus dan L.monocytogenes were not significantly different $(P>0.05)$.

The two isolates could inhibit all bacteria during the experiment at $100^{\circ} \mathrm{C}$. L.plantarum 7CT3 isolates could inhibit S.thypimurium, S.aureus and Pseudomonas spp. with a relatively similar zone of inhibition without significant difference ( $P>0.05)$. 20CT8 isolates showed a higher inhibition at $100^{\circ} \mathrm{C}$ compared to 50 and $0^{\circ} \mathrm{C}$ across the indicator bacteria. The antimicrobial activity of L.plantarum 20 CT8 isolates at $100^{\circ} \mathrm{C}$ was successful in inhibiting all indicator bacteria with a zone of inhibition of $17.4 \mathrm{~mm}$.

Antimicrobial activity of L.plantarum 3CT7 dan $20 \mathrm{CT} 8$ isolates was stable at the temperature of $0 ; 50$ and $100^{\circ} \mathrm{C}$ for 30 minutes, although the $3 \mathrm{CT} 7$ isolates could not inhibit
E.coli at $50^{\circ} \mathrm{C}$. It was in line with a previous study (Heredia-Castro et al., 2015) that Lactobacillus isolates from Mexican Cocido cheese produced bacteriocin-like substances against S.aureus, L.innocua, E.coli and S.thypimurium using diffusion method. The antimicrobe produced was stable at $65^{\circ} \mathrm{C}$ for 30 minutes and exhibited antimicrobial activity at $\mathrm{pH}$ between 2 and 8 . It showed that bacteriocin produced from antimicrobial activity could be harnessed as the natural preservatives for pasteurized products, particularly dairy products (Heredia-Castro et al., 2015). Antimicrobe with the potential as bacteriocin showed durability in sterilization temperature of $121^{\circ} \mathrm{C}$ for 15 minutes (Kusmarwati et al., 2014) and could only serve as preservatives for high-temperature food processing. Antimicrobe that endures high temperature is the potential candidate for bacteriocin because bacteriocin is protein consisted of short peptides that remain stable under the heat and endures a wide range of $\mathrm{pH}$ value.

\section{Antimicrobial Activity during Cold Storage}

Table 3 shows that the isolates produced by both L.plantarum 7CT3 and L.plantarum 20CT8 show antimicrobial activity during cold storage. The isolates were stored at $5^{\circ} \mathrm{C}$ for 60 days and the test was conducted every 15 days. L.plantarum 7CT3 isolates had a relatively similar diameter across the indicator bacteria and not significantly different $(P>0.05)$ from condition before storage. L.plantarum 20CT8 isolates had a higher inhibition against Pseudomonas spp. and significantly different against all other bacteria $(P<0.05)$. During the 15-day cold storage, L.plantarum 7CT3 showed the highest inhibition against Pseudomonas spp. $17.78 \mathrm{~mm}$ and was significantly different $(P<0.05)$ from other indicator bacteria. On the contrary, L.plantarum 20 СT8 did not show different inhibitory properties across indicator bacteria. During the 30-day storage, both L.plantarum 7CT3 and L.plantarum 20CT8 could inhibit all indicator bacteria and showed 
Triana Setyawardani et al. /Animal Production. 21(3):167-174, 2019

Accredited by Kemenristek Dikti No 32a/E/KPT/2017. ISSN 1411-2027

Table 3. Zone of inhibition of $\angle$ plantarum $7 C T 3$ and $20 C T 8$ isolates during cold storage time

\begin{tabular}{|c|c|c|c|c|c|}
\hline \multirow{2}{*}{ Isolates/Indicator bacteria } & \multicolumn{5}{|c|}{ Cold storage time (days) } \\
\hline & 0 & 15 & 30 & 45 & 60 \\
\hline \multicolumn{6}{|l|}{ L.plantarum 7CT3 } \\
\hline S.thypimurium & $16.78 \pm 0.58$ & $12.56 \pm 0.96^{b}$ & $16.11 \pm 2.55^{\mathrm{b}}$ & $11.31 \pm 1.15^{b}$ & $12.33 \pm 0.58^{d}$ \\
\hline E.coli & $16.44 \pm 2.22$ & $13.78 \pm 2.12^{b}$ & $21.67 \pm 2.91^{\mathrm{a}}$ & $12.22 \pm 0.77^{b}$ & $0.00 \pm 0.00^{c}$ \\
\hline S.aureus & $16.11 \pm 0.51$ & $15.33 \pm 1.15^{\mathrm{ab}}$ & $13.55 \pm 2.12^{\mathrm{bc}}$ & $10.33 \pm 0.58^{b}$ & $14.00 \pm 0.00^{b}$ \\
\hline Pseudomonas spp.p & $18.34 \pm 2.52$ & $17.78 \pm 2.27^{\mathrm{a}}$ & $15.00 \pm 0.00^{b c}$ & $18.00 \pm 0.00^{\mathrm{a}}$ & $15.00 \pm 0.00^{\mathrm{a}}$ \\
\hline L.monocytogenes & $15.33 \pm 0.58$ & $15.00 \pm 0.00^{\mathrm{ab}}$ & $12.00 \pm 0.00^{b}$ & $11.33 \pm 0.58^{b}$ & $13.00 \pm 0.00^{c}$ \\
\hline \multicolumn{6}{|l|}{ L.plantarum $20 C T 8$} \\
\hline S.thypimurium & $16.78 \pm 1.26^{\mathrm{b}}$ & $14.89 \pm 0.58$ & $16.33 \pm 2.08^{b}$ & $11.83 \pm 0.93^{\mathrm{abc}}$ & $13.67 \pm 1.15^{b}$ \\
\hline E.coli & $15.00 \pm 1.00^{b}$ & $14.89 \pm 1.71$ & $20.56 \pm 0.96^{\mathrm{a}}$ & $14.00 \pm 3.00^{\mathrm{ab}}$ & $12.67 \pm 2.08^{b}$ \\
\hline S.aureus & $16.11 \pm 0.51^{b}$ & $16.89 \pm 1.92$ & $16.00 \pm 0.00^{b}$ & $11.33 \pm 0.58^{b c}$ & $17.00 \pm 0.00^{\mathrm{a}}$ \\
\hline Pseudomonas spp.p & $19.34 \pm 1.12^{\mathrm{a}}$ & $18.33 \pm 2.08$ & $16.67 \pm 0.58^{b}$ & $14.33 \pm 0.58^{\mathrm{a}}$ & $14.00 \pm 0.00^{b}$ \\
\hline L.monocytogenes & $15.33 \pm 0.58^{b}$ & $17.33 \pm 0.58$ & $13.67 \pm 0.58^{c}$ & $10.67 \pm 0.58^{c}$ & $13.00 \pm 0.00^{b}$ \\
\hline
\end{tabular}

Values bearing different superscripts within column, either L.plantarum 7CT3 or L.plantarum 20CT8, show significant differences $(P<0.05)$

significant difference $(\mathrm{P}<0.05)$ in E.coli compared to the other bacteria. The highest inhibition was against E.coli (21.67 and 20.56 $\mathrm{mm}$ ) and the lowest was L.monocytogenes (12.00 and $13.67 \mathrm{~mm}$ ). During the 45-day storage, the isolates of both L.plantarum 7CT3 and plantarum 20CT8 showed the highest inhibition against Pseudomonas spp. 18 and $14.33 \mathrm{~mm}$, respectively, and was significantly different from the other indicator bacteria. L.plantarum 20CT8 and L.plantarum 7CT3 isolates during the 60-day storage was not capable of inhibiting E.coli, but showed inhibitory properties against the other indicator bacteria. L.plantarum 20CT isolates showed the highest inhibition against S.aureus and was significantly different from other bacteria $(P<0.05)$. In the cold storage, antimicrobial activity survived up to 60 days in L.plantarum isolates and most of the bacteria. It showed that antimicrobial activity in both isolates could inhibit the indicator bacteria for 60 days. E.coli could not be inhibited during 60-day of cold storage by L.plantarum 7CT3 isolates, but inhibited by 20 CT8 isolates. Therefore, L.plantarum 7CT3 was more effective in inhibiting E.coli in cold storage for up to 6 days.

\section{Antimicrobial Activity in Different pH Values}

Table 4 shows that both isolates grown in the range of $\mathrm{pH}$ from 2 to 8 could inhibit $\mathrm{S}$. thypimurium, E.coli, S.aureus and Pseudomonas spp. Both isolates did not show inhibition in $\mathrm{pH}$ 2. Media with $\mathrm{pH} 4$ showed significantly different $(\mathrm{P}<0.05)$ zone of inhibition against the bacteria. L.plantarum 7CT3 isolates showed the highest inhibition against Pseudomonas spp. $(17.78 \mathrm{~mm}$ ) while L.plantarum 20CT8 had the highest inhibition against L.monocytogenes.

At $\mathrm{pH} 8$, the highest and lowest average of L.plantarum 7CT3 isolates inhibition was against E.coli (15.67 mm) and Pseudomonas spp. (11.33 $\mathrm{mm})$, respectively. In L.plantarum 20CT8 isolates, the highest and lowest average of inhibition was against Pseudomonas spp. (18 $\mathrm{mm})$ and L.monocytogenes (12 $\mathrm{mm})$, respectively. The highest mean inhibition in isolates $3 \mathrm{CT} 7$ was obtained in $\mathrm{pH}$ value 4 , followed by $\mathrm{pH} 8$. It indicated that both isolates are applicable to different ranges of $\mathrm{pH}$ value.

The changing antimicrobial activity was affected by different environmental condition, such as $\mathrm{pH}$. Antimicrobial durability in a wide range of $\mathrm{pH}$ value will determine the metabolite application produced by LAB. Studies by FayolMessaoudi et al. (2005) and (Zacharof and Lovitt, 2012) reported that antibacterial was more effective in absorbing the surface of the bacteria in $\mathrm{pH}<5.0$. Research showed that the antimicrobial properties survived in a wide range of $\mathrm{pH}$ values from 4 to 10 in all indicator bacteria. It was in line with Mezaini et al. (2009) 
Table 4. Antimicrobial activity of L.plantarum 7CT3 and 20 CT8 isolates in a range of pH

\begin{tabular}{|c|c|c|c|c|}
\hline \multirow{2}{*}{ Isolates/Indicator bacteria } & \multicolumn{4}{|c|}{$\mathrm{pH}$} \\
\hline & 2 & 4 & 6 & 8 \\
\hline \multicolumn{5}{|l|}{ L.plantarum 7СТ3 } \\
\hline S.thypimurium & $7.67 \pm 0.58^{b}$ & $14.33 \pm 0.96^{b}$ & $13.33 \pm 0.58^{\mathrm{a}}$ & $15.00 \pm 0.00^{\mathrm{ab}}$ \\
\hline E.coli & $10.33 \pm 0.58^{\mathrm{a}}$ & $13.78 \pm 2.12^{b}$ & $10.67 \pm 0.58^{c}$ & $15.67 \pm 0.58^{\mathrm{a}}$ \\
\hline S.aureus & $10.00 \pm 0.00^{\mathrm{a}}$ & $15.33 \pm 1.15^{\mathrm{ab}}$ & $13.00 \pm 1.00^{\mathrm{ab}}$ & $13.33 \pm 0.58^{c}$ \\
\hline Pseudomonas spp.p & $8.00 \pm 0.00^{b}$ & $17.78 \pm 2.27^{\mathrm{a}}$ & $12.00 \pm 0.00^{b}$ & $11.33 \pm 1.15^{d}$ \\
\hline L.monocytogenes & $0.00 \pm 0.00^{c}$ & $15.00 \pm 0.00^{\mathrm{ab}}$ & $7.33 \pm 0.58^{d}$ & $14.33 \pm 0.58^{\mathrm{bc}}$ \\
\hline \multicolumn{5}{|l|}{ L.plantarum $20 \mathrm{CT} 8$} \\
\hline S.thypimurium & $10.67 \pm 0.58^{c}$ & $13.33 \pm 0.58^{c}$ & $15.33 \pm 0.58$ & $16.33 \pm 0.58^{b}$ \\
\hline E.coli & $12.67 \pm 0.58^{\mathrm{ab}}$ & $14.50 \pm 0.71^{\mathrm{ab}}$ & $12.67 \pm 1.53$ & $16.00 \pm 1.73^{b}$ \\
\hline S.aureus & $12.33 \pm 2.08^{b c}$ & $13.67 \pm 0.58^{b}$ & $13.00 \pm 1.00$ & $13.33 \pm 0.58^{c}$ \\
\hline Pseudomonas spp.p & $14.33 \pm 0.58^{\mathrm{a}}$ & $13.00 \pm 0.00^{c}$ & $13.00 \pm 0.00$ & $18.00 \pm 0.00^{\mathrm{a}}$ \\
\hline Lmonocytogenes & $0.00+0.00^{\mathrm{d}}$ & $15.00+1.00^{\mathrm{a}}$ & $12.67+1.53$ & $12.33+0.58^{c}$ \\
\hline
\end{tabular}

that antimicrobial activity could survive in $\mathrm{pH}$ between 4.0 and 8.0. Meanwhile, Pinto et al. (2009) stated that Pediococcus pentosaceus and E.faecium could maintain the antimicrobial activity in $\mathrm{pH} 2.0$ to 8.0 before vanishing in $\mathrm{pH}$ 12. Antimicrobial activity in a wide range of $\mathrm{pH}$ will accommodate the application of the product.

\section{Conclusion}

Isolates L.plantarum 3CT7 and L.plantarum $8 \mathrm{CT} 20$ exhibit antimicrobial activities in a wide range of $\mathrm{pH}$ value (2.0-8.0); from low to high temperatures $\left(0^{\circ} \mathrm{C}-100^{\circ} \mathrm{C}\right)$, and under cold storage for 60 days. Both isolates are the potential natural preservatives.

\section{Acknowledgement}

The authors express their gratitude to the Ministry of Research, Technology and Higher Education of Indonesia for the research grant under the scheme of Excellence Higher Education Institution Research $201 \Theta$ No. 1633/UN23.14/PN.01.00/2018 and Contract/No. 1930/UN23.14/PN/2018 .

\section{References}

Arisanti R.R., C. Indriani, and S.A. Wilopo. 2018. Kontribusi agen dan faktor penyebab kejadian luar biasa keracunan pangan di Indonesia: kajian sistematis. Berita Kedokteran Masyarakat 34: 99106.
Assefa E., F. Beyene, and A. Santhanam. 2008. Effect of temperature and $\mathrm{pH}$ on the antimicrobial activity of inhibitory substances produced by lactic acid bacteria isolated from Ergo, an Ethiopian traditional fermented milk. African Journal of Microbiology Research 2: 229-234.

Çadirci B.H., and S. Çitak. 2005. A comparison of two methods used for measuring antagonistic activity of lactic acid bacteria. Pak. J. Nutr 4: 237-241.

Dinev T., G. Beev, M. Tzanova, S. Denev, D. Dermendzhieva, and A. Stoyanova. 2018. Antimicrobial activity of Lactobacillus plantarum against pathogenic and food spoilage microorganisms: a review. Bulgarian Journal of Veterinary Medicine 21.

Fayol-Messaoudi D., C.N. Berger, M.H. CoconnierPolter, V. Lievin-Le Moal, and A.L. Servin. 2005. $\mathrm{pH}-$, Lactic acid-, and non-lactic acid-dependent activities of probiotic Lactobacilli against Salmonella enterica Serovar Typhimurium. Appl Environ Microbiol 71: 6008-6013.

Hartmann H.A., T. Wilke, and R. Erdmann. 2011. Efficacy of bacteriocin-containing cell-free culture supernatants from lactic acid bacteria to control Listeria monocytogenes in food. International Journal of Food Microbiology 146: 192-199.

Heredia-Castro P.Y., J.I. Méndez-Romero, A. Hernández-Mendoza, E. Acedo-Félix, A.F. González-Córdova, and B. Vallejo-Cordoba. 2015. Antimicrobial activity and partial characterization of bacteriocin-like inhibitory substances produced by Lactobacillus spp. isolated from artisanal Mexican cheese. Journal of dairy science 98: 8285-8293.

Khay E.O., M. Idaomar, L. Castro, P. Bernárdez, N. Senhaji, and J. Abrini. 2013. Antimicrobial activities of the bacteriocin-like substances produced by lactic acid bacteria isolated from 
Moroccan dromedary milk. African Journal of Biotechnology 10: 10447-10455.

Kusmarwati A., F.R. Arief, and S. Haryati. 2014. Eksplorasi bakteriosin dari bakteri asam laktat asal rusip bangka dan kalimantan. Jurnal pascapanen dan bioteknologi kelautan dan perikanan 9: 29-40.

Mezaini A., N-E Chihib, A. Dilmi Bouras, N. NedjarArroume, and J.P. Hornez. 2009. Antibacterial activity of some lactic acid bacteria isolated from an Algerian dairy product. Journal of environmental and public health: 1-6.

Pinto A.L., M. Fernandes, C. Pinto, H. Albano, F. Castilho, P. Teixeira, and P.A. Gibbs. 2009. Characterization of anti-Listeria bacteriocins isolated from shellfish: potential antimicrobials to control non-fermented seafood. International Journal of Food Microbiology 129: 50-58.

Setyawardani T., A.H.D. Rahardjo, and M. Sulistyowati. 2017. Chemical Characteristics of Goat Cheese with Different Percentages of Mixed Indigenous Probiotic Culture during Ripening. Tropical Animal Science Journal 40: 55-62.

Setyawardani T., W.P. Rahayu, R.R.A. Maheswari, and N.S. Palupi. 2014. Antimicrobial activity and adhesion ability of indigenous lactic acid bacteria isolated from goat milk. International Food Research Journal 21: 959-964.

Tejero-Sariñena S., J. Barlow, A. Costabile, G.R. Gibson, and I. Rowland. 2012. In vitro evaluation of the antimicrobial activity of a range of probiotics against pathogens: Evidence for the effects of organic acids. Anaerobe 18: 530-538.

Teneva D., R. Denkova, B. Goranov, Z. Denkova, and G. Kostov. 2017. Antimicrobial activity of Lactobacillus plantarum strains against Salmonella pathogens. Ukrainian food journal 6: 125-133.

Zacharof MP, and RW Lovitt. 2012. Bacteriocins produced by lactic acid bacteria; a review article. APCBEE Procedia 2: 50-56.

Zouhir A., E. Kheadr, I. Fliss, and J.B. Hamida. 2011. Partial purification and characterization of two bacteriocin-like inhibitory substances produced by bifidobacteria. African Journal of Microbiology Research 5: 411-418. 